\title{
GOMMENTS
}

\section{RETHINKING THE STANDARD FOR NEW TRIAL MOTIONS BASED UPON RECANTATIONS AS NEWLY DISCOVERED EVIDENCE}

\author{
JANICE J. REPKA
}

On April 4, 1985, a young woman told an Illinois court that her story of rape and kidnapping, upon which a still incarcerated man had been convicted six years earlier, was a complete fabrication. ${ }^{1}$ Due to her evasive demeanor and certain inconsistencies in her testimony, however, the judge chose not to believe her and, following well-established precedents, sent the convicted man back to jail. ${ }^{2}$ In the media firestorm that resulted, a shocked public expressed its surprise and outrage that an "innocent" man could continue to serve time for a crime which the "victim" later claimed had never happened. ${ }^{3}$ Soon thereafter, the Illi-

†B.A. 1983, Point Park College; J.D. Candidate 1987, University of Pennsylvania.

${ }^{3}$ See Woman Recants a Rape Charge Six Years Later, N.Y. Times, Mar. 30, 1985, at A6, col. 1. The woman claimed that she created the rape story because she thought she might have been pregnant and feared the reaction of her foster parents. She said that she ripped her clothing, scratched her body with broken glass, inflicted bruises upon herself, and accused the man eventually convicted because his photograph strongly resembled the police sketch that she had created. See generally People v. Dotson, 99 Ill. App. 3d 117, 119-20, 424 N.E.2d 1319, 1321-22 (1981) (unsuccessful appeal of original trial providing summary of the facts as found at the original trial); Starr, Who Is the Real Victim?, 105 NEWsweEk, May 20, 1985, at 69, 69-73 (providing a detailed, albeit commercialized, account of the highly publicized recantation incident). For the "victim's" recanted account of the story, see C. WEBB, ForGIVE ME (1985) (detailing "victim's" autobiographical account of the incident).

2 See Same Verdict: Recanting to No Avail, Time, Apr. 22, 1985, at 24, 24; Recanting of a Rape Charge Fails to Free Convict, N.Y. Times, Apr. 12, 1985, at A1, col. 2; see also Black, Why Judge Samuels Sent Gary Dotson Back to Prison, 71 A.B.A. J. 56, $56-59$ (1985) (article based on interview with judge who rejected the recantation testimony in which the judge's reasons for doing so are explored); Starr, More Than a Case of Rape, 105 NEWSWEEK, Apr. 22, 1985, at 21, 21 (brief look at the evidence presented at the hearing to vacate and reactions to the judge's ruling).

3 See, e.g., Why It's Tough to Take It Back, TIME, Apr. 29, 1985, at 75, 75; Recantation, Incantation and Rape, N.Y. Times, Apr. 16, 1985, at A26, col. 1 ("Confidence in American justice cannot rest easily when [a person] is sent back to jail on the word of a woman who is, one way or the other, an acknowledged liar."); Debate Surrounds Rape Decision, N.Y. Times, Apr. 13, 1985, at A1, col. 1. 
nois governor, acting under great public pressure, commuted the convict's sentence to time served. ${ }^{4}$ The freed felon's subsequent motion for a new trial based on the recantation testimony was denied. ${ }^{5}$ While this case was unusual enough to become something of a public curiosity, the situation it presented is not one entirely uncommon to our judicial system. $^{B}$

"Recantation" denotes a formal, intentional renunciation by a witness of her former testimony. ${ }^{7}$ Recantations have been presented to courts as a form of evidence warranting a new trial frequently enough that established rules for their treatment have been developed. ${ }^{8}$ Although treatment varies somewhat among jurisdictions, recantations are typically viewed with suspicion ${ }^{\theta}$ and are the basis for new trials only in extraordinary $\operatorname{cases}^{10}$ in which the judge hearing the recantation testimony is reasonably well satisfied that the original trial testimony was false ${ }^{11}$ and that a new trial "might" cause a different result ${ }^{12}$ or would "probably" result in acquittal." One commentator has said, "No court

See N.Y. Times, May 13, 1985, at A1, col. 2. For accounts of the clemency hearings, see N.Y. Times, May 12, 1985, at A20, col. 1; N.Y. Times, May 11, 1985, at A11, col. 2; N.Y. Times, May 10, 1985, at A16, col. 1.

- See N.Y. Times, Aug. 20, 1985, at A19, col. 1 (discussing August 14, 1985 unpublished opinion of Judge Richard J. Fitzgerald of the Cook County Circuit Court).

- Although members of the bar and the media suggested that this recantation case was unique-see N.Y. Times, Apr. 13, 1985, at A1, col. 1, A6, col. 1 ("[N])one could recall a previous case in which the recantation was by the accuser, and the only witness."); N.Y. Times, May 9, 1985, at A25, col. 1 (case is "profoundly different" because it draws into question whether there was a crime)-there are in fact many recorded cases in which a victim or a sole prosecuting witness has recanted. See, e.g., cases collected in Annotation, Recantation by Prosecuting Witness in Sex Crime As Ground For New Trial, 51 A.L.R. 3D 907 (1973).

7 See 8A R. Cipes, Moore's Federal Practice-Criminal Rules If 33.05 (2d ed. 1981).

${ }^{8}$ See Thacker v. Commonwealth, 453 S.W.2d 566, 568 (Ky. 1970) (explaining special rules applicable to situations of recanted testimony).

- See Nilva v. United States, 212 F.2d 115, 124 (8th Cir. 1954) (motion looked upon with distrust and disfavor); Harrison v. United States, 7 F.2d 259, 262 (2d Cir. 1925) ("[S]uch testimony is for obvious reasons looked upon with the utmost suspicion."). More generally, applications for a new trial based on any type of newly discovered evidence are not favored. See 58 AM. Jur. 2D New Trial \& 164 (1971).

10 See, e.g., Peterson v. State, 426 So. 2d 494, 497 (Ala. Crim. App. 1982) (courts generally pay little regard to recantations and grant new trials based upon them only in extraordinary and unusual cases); People v. Marquis, 344 Ill. 261, 265, 176 N.E. 314, 315 (1931) (same); Comment, Criminal Law-New Trial-Credibility of New Evidence-Smith v. State, 29 CoNN. B.J. 264, 268 (1955) (new trials should be granted only in extraordinary situations).

11 See 9 Federal Procedure § 22:985 (L. Ed. 1982).

12 See Larrison v. United States, 24 F.2d 82, 87-88 (7th Gir. 1928).

13 See United States v. Krasny, 607 F.2d 840, 844-45 (9th Cir. 1979), cert. denied, 445 U.S. 942 (1980) (expressly rejecting the Larrison "possibility" standard); see generally 12 C. ScotTI, CyClopedia of Federal Procedure $§ 49.31$ (3d ed. 1983) 
wishes a defendant to remain in jail if he has discovered evidence showing that he is not guilty, but after a man has had his day in court, and has been fairly tried, there is a proper reluctance to give him a second trial."14 Relatively few new trials based on the unknowing use of perjured testimony have been granted. ${ }^{15}$

This Comment dissects the legal treatment of recantations, focusing especially on the recantations of victims and sole prosecution witnesses. Part I of this Comment briefly discusses the evolution of the current treatment of recantation evidence. Part II focuses on problems and inadequacies under current law and provides a deeper analysis of particularly troubling areas of recantation treatment. The first problem

(discussing the split of authority on whether the perjury of a government witness as newly discovered evidence should warrant a new trial only when such newly discovered evidence "probably would result in an acquittal," or also when an acquittal "might or possibly would" result).

143 G. Wright, Federal Practice and Procedure, Griminal 2d $\S 557$, at 315 (1982).

1s See id. § 557.1, at 347 n.23; Note, Ninth Circuit Adopts Berry Standard for New Trials Based Upon Perjured Testimony, 11 Golden Gate U.L. Rev. 171, 181 (1981). In the following cases, state courts either granted new trials or ruled that it was error to deny new trials based upon newly discovered recantation evidence. See State v. Hickle, 133 Ariz. 234, 650 P.2d 1216 (1982); Roath v. State, 185 Ark. 1039, 50 S.W.2d 985 (1932); Meyers v. State, 111 Ark. 299, 163 S.W. 1177 (1914); Bussey v. State, 69 Ark. 545, 64 S.W. 268 (1901); People v. William, 57 Cal. 2d 263, 368 P.2d 353, 18 Cal. Rptr. 729 (1962); People v. Huskins, 245 Cal. App. 2d 859, 54 Cal. Rptr. 253 (1966); Solis v. State, 262 So. 2d 9 (Fla. Dist. Ct. App.), cert. denied, 265 So. 2d 372 (Fla. 1972), overruled, 374 So. $2 d 1022$ (Fla. Dist. Ct. App. 1979); O'Brien v. State, 206 So. 2d 217 (Fla. Dist. Ct. App. 1968), overruled, Mollica v. State, 374 So. 2d 1022 (Fla. 1979), cert. denied, 386 So. 2d 639 (Fla. 1980); People v. Busch, 228 Ill. App. 11 (1923); Key v. State, 235 Ind. 172, 132 N.E. 143 (1956); Dennis v. State, 103 Ind. 142, 2 N.E. 349 (1885); State v. Mounkes, 91 Kan. 653, 138 P. 410 (1914); Mullins v. Commonwealth, 375 S.W.2d 832 (Ky. 1964); Tyree v. Commonwealth, 160 Ky. 706, 170 S.W. 33 (1914); People v. Smallwood, 306 Mich. 49, 10 N.W.2d 303 (1943); Bates v. State, 32 So. 915 (Miss. 1902); State v. Moberly, 121 Mo. 604, 26 S.W. 364 (1894); State v. Greeno, 135 Mont. 580, 342 P.2d 1052 (1959); State v. Chavez, 87 N.M. 38, 528 P.2d 897 (1974); People v. Friday, 90 N.Y. Sup. Ct. 240, 31 N.Y.S. 399 (1894); Martin v. State, 34 Okla. Crim. 274, 246 P. 647 (1926); Commonwealth v. Mosteller, $446 \mathrm{~Pa} .83,284$ A.2d 786 (1971); Commonwealth v. McCloskey, $270 \mathrm{~Pa}$. Super. 584, 411 A.2d 1239 (1979); Commonwealth v. Krick, $164 \mathrm{~Pa}$. Super. 516, 67 A.2d 746 (1949); Wadkins v. State, 102 Tex. Crim. 292, 277 S.W. 684 (1925); Mann v. State, 44 Tex. 642 (1876); Hodnett v. City of Danville, 152 Va. 955, 146 S.E. 281 (1929); Hines v. Commonwealth, 136 Va. 728, 117 S.E. 843 (1923); Powell v. Commonwealth, 133 Va. 741, 112 S.E. 657 (1922); State v. Ramel, 65 Wash. 2d 326, 396 P.2d 988 (1964); State v. Elliott, 6 Wash. 2d 393, 107 P.2d 927 (1940); State v. Powell, 51 Wash. 372,98 P. 741 (1909); State v. York, 41 Wash. App. 538, 704 P.2d 1252 (1985). In the following cases, federal courts issued holdings similar to those issued by state courts in the cases noted directly above. See United States v. Wallace, 528 F.2d 863 (4th Cir. 1976); United States v. Meyers, 484 F.2d 113 (3d Cir. 1973); Newsome v. United States, 311 F.2d 74 (5th Cir. 1962); Pettine v. New Mexico, 201 F. 489 (8th Cir. 1912); United States v. Mitchell, 29 F.R.D. 157 (D.N.J. 1962); United States v. Miller, 61 F. Supp. 919 (D.C.N.Y. 1945). This list should not be relied upon as exhaustive. 
to be explored is the danger and inaccuracy of indulging a broad presumption that all recantations are inherently untrustworthy. The next problem explored is the unrealistically demanding and perhaps overly discretionary credibility standards currently employed, in part because of this presumption. Next, the possible due process issues raised by making the new trial standard too strict will be addressed. Additionally, the Comment will examine the popular view that such cases are best handled through use of the executive clemency power. Part III of this Comment discusses minority views advocating alternative judicial treatment of recantation evidence. Finally, Part IV suggests a proposal that could be used to relax the standard in certain cases while continuing to guard carefully against the unwarranted granting of new trials.

\section{Doctrinal Evolution}

An analysis of the evolution of the treatment of recantation reveals that encouraging strides have been made toward ensuring the availability of a vehicle through which justice may be achieved. Regrettably, however, the history of recantation treatment reveals the inadequacies that have plagued, and remain in, our system. While a clear picture of the past is somewhat difficult to discern because of the lack of uniformity among the states, a generalized account of the evolution of treatment of recantation is possible.

Before the 1900's there was frequently no judicial remedy for cases in which perjury by a material witness was discovered postconviction. ${ }^{16}$ It has been estimated that more than half of all criminal cases tried near the beginning of this century contained some such tainted evidence: perjury was commonplace. ${ }^{17}$ In some of the more shocking cases defendants were convicted of having murdered individuals later found to be alive ${ }^{18}$ and of having committed robberies that never oc-

16 See National Commission on Law Observance and Enforcement, Report on CRIminal Procedure, No. 8, at $42-45$ (1931); Berman, Newly Discovered Evidence-A Defendant's Chance for A New Trial, 28 N.Y.L. ScH. L. REv. 31, 31 (1983). See generally Comment, Criminal Law and Procedure-Remedies Available to Convicted Defendant When New Facts Are Found, 39 Mrch. L. REv. 963, 963-64 (1941) [hereinafter Remedies] ("For centuries it seems to have been assumed that there was no method by which the verdict of a jury, having once become final, might be set aside.")

${ }^{17}$ See Whitman, A Proposed Solution to the Problem of Perjury in Our Courts, 59 Drck. L. REv. 127, 145 (1955) (concluding that it is "more difficult to convict a perjurer than a murderer," and that state laws ought to require the "proof beyond a reasonable doubt" standard rather than follow the rule that two witnesses and sufficient corroboration are necessary to prove perjury).

${ }^{18}$ See E. Borchard, Convicting the InNOcent 39-44, 50-57 (1932). 
curred. ${ }^{10}$ Utterly erroneous convictions were affirmed by appellate courts because they were incompetent on quasi-jurisdictional grounds to consider evidence of perjury discovered postconviction as grounds for a new trial. ${ }^{20}$ The courts lacked an inherent power to grant such relief. ${ }^{21}$ An appeal for executive clemency was often viewed as the only recourse. ${ }^{22}$

Frustrated defendants often sought remedy through the common law writs, but these were generally of little assistance. The highly technical writ of coram nobis, which lies to correct errors of fact not apparent in the record that would have prevented judgment had they been known, ${ }^{23}$ proved to be ineffective because most courts rejected its application in the recantation context. ${ }^{24}$ The writ of habeas corpus also proved to be an impotent remedy in this area, as the courts held that it would not be issued unless state officials "knowingly" used the perjured testimony. ${ }^{25}$

19 See id. at 331-34.

${ }^{30}$ See id. at 375-76. Typically the incompetency of a court to consider perjury discovered postconviction as ground for a new trial resulted from the fact that a new trial could not be granted upon matters not appearing in the record. See infra note 22.

21 See Berman, supra note 16, at 31.

22 See People v. Mooney, 176 Cal. 105, 109, 167 P. 696, 697 (1917) (executive, not court, may grant relief via pardoning power when newly discovered evidence surfaces), rehearing en banc, $178 \mathrm{Cal}$. 525, 530, 174 P. 325, 327 (1918) (perjured testimony or concealment or suppression of material evidence improper basis to set aside judgment), cert. denied, 248 U.S. 579 (1918); State v. Sadowski, 256 S.W. 753, 756 (Mo. 1923) (court can only consider errors on face of record; defendant should appeal to pardoning board with newly discovered evidence of the confession of another person to the crime).

2s See Remedies, supra note 16 , at 967.

24 See Mooney, 178 Cal. at 529-30, 174 P. at 326-27 (writ of coram nobis does not lie to readjudicate issue of fact such as truth or falsity of testimony); O'Callaghan v. State, 461 So. 2d 1354, 1356 (Fla. 1984) (motion for leave to file a petition for writ of error coram nobis on ground that material witness recanted testimony denied because change of testimony would not have conclusively prevented entry of judgment under circumstances); see also Donnelly, Unconvicting The Innocent, 6 VAND. L. REv. 20, 24-28 (1952) (stating that most courts have refused to extend the writ of coram nobis to cases putting in issue any fact adjudicated at the trial or to convictions based on perjured testimony unless knowingly used by the prosecution); Remedies, supra note 16, at 968-70 (American courts have engrafted so many conditions upon the availability of the writ of coram nobis that its usefulness is all but destroyed.); Comment, Relief From Convictions Based Upon Perjured Testimony-A Proposal For A Reasonable Standard, 11 SANTA ClaRa Law. 316, 320-22 (1971) [hereinafter Relief] (standard for writ of coram nobis in California is so high that it is useless). The writ is, however, considered a proper vehicle by a few courts, which continue to use it. See, e.g., Teat v. State, 453 So. $2 \mathrm{~d} 760,761$ (Ala. 1984) (affirming denial of petition for writ of coram nobis on the merits).

${ }^{20}$ See Relief, supra note 24, at 322-23. See generally Murray, Convictions $O b$ tained By Perjured Testimony: A Comparative View, 27 Oнго ST. L.J. 102, 102-08 (1966) (arguing that the distinction between knowing and unknowing use is artificial and should be abandoned). 
Defendants thus found themselves battling over the technicalities of which remedy, if any, was available, rather than over whether an injustice had occurred. ${ }^{26}$ Further, even if a vehicle for relief could be found, in some jurisdictions conviction of the recanting witness for perjury had to be obtained before the recantation testimony would be considered by the courts. ${ }^{27}$ State legislatures responded with statutes empowering courts to grant new trials on the basis of newly discovered evidence. ${ }^{28}$ Commentators proposed a uniform rule that would have allowed a new trial to be granted on the ground that "new and material evidence, which if introduced at the trial would probably have changed the verdict or finding of the court, [has subsequently been] discovered which the defendant could not with reasonable diligence have discovered and produced upon the trial."29 Initially even this rule for challenging a conviction based upon subsequently recanted testimony met with resistance. Some courts held that where the credibility of a witness had been examined at trial, that witness's recantation was merely impeaching and thus not a ground for a new trial. ${ }^{30}$ Other courts noted that the rule applied to civil but not to criminal cases. ${ }^{31}$ Eventually, however, the commentators' view became widely accepted as an appropriate ground for challenging a conviction based on recanted testimony; new trials can now be sought in nearly all jurisdictions on the ground of newly discovered evidence. ${ }^{32}$

${ }^{26}$ See Murray, supra note 25, at 103-04; see also Relief, supra note 24, at $322-$ 23 (discussing the intricacies of a writ of coram nobis and a writ of habeas corpus and why neither provides relief for the innocently convicted in California).

${ }_{27}$ See State v. Fuentes, 66 N.M. 52, 59, 342 P.2d 1080, 1084 (1959); Note, Criminal Law-Judicial Discretion in Considering Recantation as a Ground for a New Trial, 39 MinN. L. Rev. 316, 318 (1955).

${ }_{28}$ See, e.g., N.Y. CRIM. Proc. LAw \& 440.10(1)(g) (McKinney 1983); see also Berman, supra note 16, at 31-32 (discussing the development of this New York statute into its modern day version). See generally Code of CRIMINal Procedures 1052-53 (Official Draft 1930) (listing existing state statutes authorizing the granting of new trials on the basis of newly discovered evidence).

'28 Code of Criminal Procedure, supra note 28, at 139-40.

so See Donnelly, supra note 24 , at 23 n.14 (recantations are merely impeaching). This view was dispelled rather quickly. See $3 \mathrm{C}$. WRIGHT, supra note 14, $\$ 557.1$, at 347 ("Although [a recantation] is not newly discovered evidence at all in the real sense, but only an assertion that the old testimony is false, it is not merely impeaching, but is substantial and material testimony .....").

s1 See, e.g., State v. Casey, 201 N.C. 620, 629, 161 S.E. 81, 86 (1931) (Brogden, J., concurring).

32 See 58 AM. JuR. 2D New Trial $\S 164$ (1971). Some courts have expressly recognized an inherent power in themselves to grant such relief absent specific statutory authority. See, e.g., State v. Mooney, 670 S.W.2d 510, 515-16 (Mo. Ct. App. 1984) (in the absence of applicable rules or statutes, the court has inherent power to remand as justice requires); State v. Fuentes, 66 N.M. 52, 60, 342 P.2d 1080, 1085 (1959) (inherent power to prevent miscarriage of justice enables court to permit filing of new trial motion). 
Most courts have derived the requirements for a general new trial motion from a standard proposed in a nineteenth century Georgia case, Berry v. State. ${ }^{33}$ The Berry test provides that a new trial may be granted on the ground of newly discovered evidence if: (1) the evidence is discovered subsequent to the trial; (2) the evidence could not have been discovered before trial by the exercise of due diligence; (3) the evidence is material; (4) the evidence will probably change the result if a new trial is granted; and (5) the evidence is not merely cumulative or impeaching. ${ }^{\text {s4 }}$

More recently, some courts have applied a purportedly less stringent new trial standard in cases where the new trial motion was based specifically upon recantation of perjured testimony. Derived from the Seventh Circuit case Larrison v. United States, ${ }^{35}$ the test provides that a new trial is to be granted when: (1) the court is reasonably well satisfied that the testimony given by a material witness is false; (2) the jury might have reached a different conclusion without such testimony; and (3) the party seeking the new trial was taken by surprise when the false testimony was given and was unable to meet it or did not know of its falsity until after trial. ${ }^{\text {s6 }}$ While it was supposed to create a more relaxed standard for recantation cases, Larrison has recently been criticized as actually imposing a more stringent test than Berry. ${ }^{37}$ Regardless of which standard is used, however, nearly all new trial motions based on unknowing use ${ }^{38}$ of perjured testimony are routinely denied by the courts because both standards impose an excessive burden on the defendant. ${ }^{39}$ Of the vast number of cases filed in the California state courts, for example, only two new trials have ever been granted on recantation grounds, ${ }^{40}$ and in the entire federal court system few motions for a new trial based on unknowing use of perjured testimony

33 $10 \mathrm{Ga} .511$ (1851).

s4 See id. at 527. Berry also imposes the requirement that the "affidavit of the witness himself should be produced, or its absence accounted for." Id.

ss 24 F.2d 82 (7th Cir. 1928).

so See id. at 87-88.

s7 See Note, supra note 15 , at $180-81$.

ss A general reference in this Comment to perjured testimony should be taken to mean perjured testimony used unknowingly by the prosecution. Where knowing use is evident, due process is denied to the defendant and the stringent standards discussed herein are for the most part inapplicable. See generally 12 C. SCOTTI, Cyclopedia of Federal Procedure $\S 4935$ (3d ed. Supp. 1983) (knowing use of perjury is prosecutorial misconduct which may serve as the ground for a new trial).

39 See infra notes $42-88$ and accompanying text.

10 See People v. Williams, 57 Cal. 2d 263, 368 P.2d 353, 18 Cal. Rptr. 729 (1962); People v. Hushins, 245 Cal. App. 2d 859, 54 Cal. Rptr. 253 (1966). See generally Relief, supra note 24, at 319 (discussing the unusual fact patterns of the two cases above). 
hare ever been successful. ${ }^{41}$

\section{Problems and Inadequacies Under Current Law}

\section{A. The Credibility Standard and Presumptive Untrustworthiness}

Although the courts have haggled much over the precise test to apply to a new trial motion based upon allegedly perjured testimony, most courts never get past the basic credibility inquiry. ${ }^{42}$ The judge hearing the new trial motion, typically the same judge who presided at the original trial, usually decides that she believes the original trial testimony rather than the recantation. ${ }^{43}$ The precise credibility standard used varies among jurisdictions. It has been held that the judge must be reasonably well satisfied that the trial testimony was false, ${ }^{44}$ convinced that the recantation is probably true, ${ }^{45}$ or reasonably certain that the recantation is genuine. ${ }^{46}$ Drawing distinctions between these standards may be likened to splitting hairs. In varying degrees, each is too difficult for defendants to meet.

The main reason that the credibility standard trial courts apply to recantations can be too stringent for an innocent person to satisfy is that the courts effectively indulge a presumption that recantations are untrustworthy. ${ }^{47}$ This presumption is so strong that some courts have

11 See, e.g., United States v. Willis, 467 F. Supp. 1111 (W.D. Pa.), vacated and indictment dismissed upon request of U.S. Attorney's Office, 606 F.2d 391 (3d Cir. 1979); United States v. Wallace, 484 F.2d 113 (3d Cir. 1973). See generally Note, supra note 15, at 181-83 (stating that a motion for a new trial is rarely granted regardless of the particular standard court uses).

12 See Note, supra note 15, at 181-83 (motions for new trial are seldom granted regardless of the standard used). The "haggling" centers on which of the two standards should be applied-the text articulated in Berry v. State, $10 \mathrm{Ga} .511$ (1851), or the test developed in Larrison v. United States, 24 F.2d 82 (7th Cir. 1928). See supra at notes 33-37 and accompanying text. The main differences between the approaches are the degree of certainty required regarding the likelihood of a different result at a new trial and whether knowledge of the prior false testimony is imputed to the jury. See Note, supra note 15 , at 176 . It has also been said that the Larrison standard differs in that it requires proof of the false testimony before application of the other elements. See id. at 181. But see Note, Criminal Procedure: Minnesota Adopts the Larrison Standard for Granting a New Trial Because of Newly Discovered Evidence: State v. Caldwell, 67 MinN. L. Rev. 1314, 1324 n.79 (1983) (suggesting that both standards impose a preliminary credibility determination before considering the evidence).

ss See 3 C. WRIGHT, supra note 14, §557.1, at 349; Note, supra note 15, at 181. See also L. Orifeld, Criminal. Procedure Under the Federal Rules § 33:49, at 332 n.6 (1967) (listing cases).

4 See United States v. Larrison, 24 F.2d 82, 87 (7th Gir. 1928).

4s See State v. Shelton, 21 N.C. App. 662, 665, 205 S.E.2d 316, 318-19, cert. denied, 285 N.C. 667,207 S.E.2d 760 (1974).

${ }^{4}$ See State v. Hegland, 355 N.W.2d 803, 806 (N.D. 1984).

17 Cf. 8A R. CIPES, supra note 7, I 33.05, at 33-44 ("Apparently the courts in effect indulge a presumption that the recantation is false. The Second Circuit has 
required a recanting witness to be convicted of perjury before the recantation testimony will even be considered, unless conviction is impossible due to the witness's death. ${ }^{48}$ The literature surrounding the legal meaning of "presumption" has stressed the lack of consistency in the courts' usage of the term. ${ }^{48}$ A definition recently offered by one author in an attempt to provide some clarity is that "a presumption is a standardized practice, under which certain facts are held to call for uniform treatment with respect to their effect as proof of other facts." ing to this definition a presumption allows a court to infer the existence of certain unknown facts once specified other facts are shown to exist. ${ }^{51}$ In this sense presumptions differ little from inferences, ${ }^{52}$ which "saturate the judicial fact-finding process." "ss A presumption, however, is mandatory upon a court; ${ }^{\text {st }}$ once the court acknowledges certain facts, it must recognize the existence of others, while an inference represents merely a permissible deduction that a court may draw from a set of facts. ${ }^{\circ B}$

The distinction between a presumption and an inference is often somewhat blurred. The proposition that recantations are suspect and inherently unreliable may be treated as a presumption as follows: since the witness has already testified as to her version of the facts, the initial testimony is true and any recantation of that testimony is not trustworthy. While the courts have not formally adopted this presumption as mandatory, the research done for this Comment uncovered no recantation case in which the substantially identical proposition that recanta-

stated, for example, that a motion based thereon should be viewed with 'the utmost suspicion.' There is some support in common experience for the rationality of this presumption") (footnote omitted).

48 See 58 AM. JUR. 2D New Trial § 175 (1971).

40 See, e.g., E. Cleary, McCormick on Evidence § 344, at 965 (3d ed. 1984) (venturing the assertion that " "presumption' is the slipperiest member of the family of legal terms, except for its first cousin, "burden of proof "); Laughlin, In Support of the Thayer Theory of Presumptions, 52 MrCH. L. REv. 195, 206-07 (1953) (listing eight senses in which the term has been used by the courts).

so E. Cleary, supra note $49, \S 342$, at 965.

61 See Home Ins. Co. v. Weide, 78 U.S. (11 Wall.) 438, $441-42$ (1870).

${ }^{82}$ Id. (describing an inference as "the application of logic or rationalization . . . to support certain deductions made from relevant experience").

63 1 S. GARD, JoNES ON Evidence \& 3.2, at 128 (6th ed. 1972).

34 Id. A presumption, however, may be rebutted where the party against whom it operates introduces proof in contradiction. See E. CLEARY, supra note $49, \S 342$, at 966.

ss See E. Cleary, supra note $49, \S 342$, at $965-66$ (suggesting that inferences drawn by a trial judge from the evidence presented should not be confused with presumptions); see also Manchester v. Dugan, 247 A.2d 827, 829 (Me. 1965) ("A presumption is a conclusion which a rule of law directs shall be made from proof of certain facts, but an inference is a deduction which reason and logic dictates shall be made from a fact situation."). 
tions are inherently unreliable has not reared its head. As one commentator has stated:

It should be noted that there are some borderline cases where the applicable rule of law falls short of requiring absolutely the assumption of facts, but does have the effect of permitting inferences to be drawn or assumptions to be made where logic might fail. Some authorities would include such situations within the definition of presumptions. ${ }^{5 B}$

The courts' treatment of recantation testimony represents such a borderline case. Although courts are not required to presume the untrustworthiness of recantation testimony, the long-standing rule that such testimony is suspect and inherently unreliable ultimately produces the same effect. Thus one could view the courts' deep historical suspicion of recantation testimony as a presumption.

A presumption may be justified on the basis of the probative value of the basic facts that support $\mathrm{it}^{\mathrm{B7}}$ or necessitated by lack of access to evidence. ${ }^{58}$ Additional justifications often advanced are expediency and public policy. ${ }^{69} \mathrm{It}$ is thus necessary to look at the contemporary purpose of a presumption, because if the original reason for the presumption has been undermined, the presumption may be no longer justifiable. ${ }^{60}$

While the courts are far from clear on the matter, two justifications frequently emerge for the presumption that recantations are inherently unreliable. The first is a long-standing judicial fear that the defendant is trying to manipulate the court by presenting a recantation induced by duress, bribery, or misplaced sympathy. ${ }^{61}$ In People $v$.

s6 1 S. GARD, supra note 53, § 3.3, at 131 (emphasis added) (citation omitted).

87 See D. Louisell, J. Kaplan, \& J. Waltz, Principles of Evidence and Proof 871-72 (1968).

S8 1 S. GARD, supra note $53, \S 3.1$, at 126.

so See id.

${ }^{60}$ See, e.g., United States v. Provident Trust Co., 291 U.S. 272, 285 (1934) (refusing to apply a conclusive presumption that a woman is capable of childbearing for as long as she lives).

B1 See, e.g., State v. Parker, 249 S.C. 139, 142, 153 S.E.2d 183, 184 (1967) ("To hold such affidavits sufficient to require the granting of a new trial would be to open the door to fraud and perjury, as well as to invite interminable delays in the disposition of causes."); 58 AM. JuR. 2D New Trial $\S 164$ (1971) (footnote omitted) ("In order to prevent, as far as possible, the fraud and imposition which defeated parties may be tempted to practice as a last resort to escape the consequence of an adverse verdict, an applicant setting up the discovery of new evidence should always be subjected to the closest scrutiny by the court."); see also Note, Criminal Law-New Trial-Recantation by State's Witness as Ground For New Trial, 22 J. CRIM. L. \& CRIMINology 599,601 (1953) (Powerful defendants would exert pressure on witnesses if courts were easily swayed by recantations.); Why It's Tough To Take It Back, supra note 3, at 75 (stating that courts have regarded recanted testimony with suspicion because of the invalid many reasons for recanting trial testimony, including intimidation, bribery and 
Shilitano, ${ }^{62}$ perhaps the most frequently cited recantation case, the court stated without citation:

Bearing in mind that the witnesses to crimes of violence are often of a low and degraded character and that after they have given their testimony they are sometimes influenced by bribery and other improper considerations, it is evident that the establishment of a rule which left the power to depend upon recantation by such witnesses would be subversive of the proper administration of justice .... There is no form of proof so unreliable as recanting testimony. In the popular mind it is often regarded as of great importance. Those experienced in the administration of the criminal law know well its untrustworthy character. ${ }^{63}$

While the court's reasoning arguably may have been "with insight correct for its day," likely to be unscrupulous is suspect. Any witness may be influenced by bribery or improper motives. But if the justification for the presumption against recantations is the likelihood of bribery or improper motive, then a jurisdiction deciding whether its cases will be governed by the presumption should determine whether a verifiable pattern of such likelihood exists. Rather than rely on such evidence, however, the courts seem to rely solely on the bald assertion that recantations are per se unreliable.

Other reasons given by courts that indulge the presumption are the need for finality of judgments and the concern for husbanding judicial resources. ${ }^{65}$ It is said that the stability and security of all verdicts would be threatened if verdicts could be set aside purely on a recanting witness's affidavit. ${ }^{66}$ As one court has aptly noted, however, the need for finality in criminal trials, though surely a strong one, has been balanced against the need to minimize injustice, and the scales have already been tipped in favor of allowing relitigation by allowing motions for a new trial based on newly discovered evidence. ${ }^{67}$ In sum, "[t]o say

misplaced sympathy). This long-standing judicial fear is apparently based on the belief that perjurious witnesses rarely recant out of remorse for participating in the conviction of an innocent person, and that recantations thus have no purpose but to manipulate the court. See C. WRIGHT, supra note $14, \S 557.1$, at 351 .

${ }_{62} 218$ N.Y. 161, 112 N.E. 733 (1916).

6s Id. at $169-70,112$ N.E. at 735-36.

64 Berman, supra note 16 , at 39 .

6s See Comment, Criminal Law-New Trial-Credibility of New Evidence-Smith v. State, 29 CoNN. B.J. 264, 268 (1955).

${ }_{68}$ See State v. Hegland, 355 N.W.2d 803, 806 (N.D. 1984).

67 See Cole v. State, 589 S.W.2d 941, 942-43 (Tenn. Crim. App. 1979). 
that it is more important to decide criminal cases and leave them undisturbed than to decide them justly is . . a reprehensible way to vindicate the judicial process." 68

Nor can the presumption against recantations be justified on the theory that lack of access to evidence necessitates it. Perhaps the presumption could be justified on this theory if case law showed the courts grasping desperately for clues as to what might have induced the recantations while surrounded by factual silence. On the contrary, however, actual evidence of duress ${ }^{69}$ or bribery ${ }^{70}$ has been discussed in the majority of the cases in which new trials were denied, and thus it does not seem that courts lack access to facts pertaining to the validity of recantations. Accordingly, the presumption against recantations serves as little more than an obstacle to an innocent person attempting to rely on a legitimate recantation.

The origin of the presumption that recantations are inherently unreliable is not well documented. Early cases indicate that the current presumption of untrustworthiness may have derived from the belief that the verdict of the jury warrants a presumption that the witness's trial testimony was true and that recanted testimony is therefore false. ${ }^{71}$ It has been shown, however, that juries have no special skills at detecting deception by witnesses. ${ }^{72}$ In fact, in recent experiments testing mock jurors' ability to recognize deceitful statements, the subjects' percentage of success was no higher than it would have been through random guessing. ${ }^{73}$ Thus the deference one might give the jury's finding in a

as Donnelly, supra note 24, at 37.

60 See, e.g., United States v. Atkins, 545 F.2d 1153, 1154 (8th Cir. 1976) (evidence of death threats); Teat v. State, 453 So. 2d 760, 761 (Ala. Crim. App. 1984) (evidence of harassment); People v. Worthen, 105 Ill. App. 3d 386, 388-89, 434 N.E.2d 423, 425 (1982) (pressures from relatives of both the defendant and the victim); State v. Carter, 66 N.C. App. 21, 31-32, 311 S.E.2d 5, 11 (1984) (pressure from fellow inmates who accused recanting codefendant of being a "snitch").

70 See, e.g., State v. Lopez, 145 Ariz. 193, 194, 700 P.2d 891, 892 (1985) (evidence that defendant offered witness financial support to induce recantation); Lipsey v. State, 170 Ga. App. 212, 214, 316 S.E.2d 774, 776 (1984) (Pope, J. and Deen, J., dissenting) (mother told incest victim staying in home for children that she could come home if she recanted); Cole v. State, 589 S.W.2d 941, 942 (Tenn. Crim. App. 1979) (pretrial evidence that defendant had asked the victim to drop the charges in exchange for money and a promise that defendant would not attack the victim again).

71 See People v. Tallmadge, 114 Cal. 427, 431, 46 P. 282, 283 (1896); People v. Marquis, 344 Ill. 261, 265, 176 N.E. 314,315 (1931).

${ }_{22}$ See Shaffer, The Defendant's Testimony, in The Psychology of Evidence and Trial Procedure 138-40 (S. Kassin \& L. Wrightsmon eds. 1985) (discussing an observer's inaccuracy in detecting deception); see also Miller \& Burgoon, Factors Affecting Assessments of Witness Credibility, in THE Psychology of THE CouRTROOM 169-94 (N. Kerr \& R. Pray eds. 1982) (providing a thorough discussion of how perceptions of credibility are made and analyzing the results of various studies).

${ }^{73}$ See Shaffer, supra note 72, at 139. 
different context may not be fully appropriate when a subsequent new trial motion raises the very question of witnesses' deceit. Even if it is entirely fair for the defendant to have the burden of persuading the court as to the veracity of the recantation because the jury's verdict is presumed to be correct, it is unfair to say that the presumption that the jury's verdict is correct warrants the further presumption that recantation evidence is inherently unreliable. The defendant may have "the laboring oar to rebut the presumption that the verdict is correct"74 but cannot reasonably be expected to advance at all against the strong tide of presumptive untrustworthiness,

Furthermore, while the courts indulge the strong presumption that all recantations are somehow tainted, they do not articulate clearly how a defendant may rebut this presumption. ${ }^{75}$ Such a presumption may not be rebuttable at all in the many factual situations in which the conviction is based mainly on the recanting witness's original trial testimony without substantial corroborating evidence. For example, a court may refuse to believe the recantation of a rape "victim," yet what more "could a defendant do ... than to have the victim swear she made up the crime"?78 Elimination of the presumption against recantations would not radically alter recantation law. While giving credence to recantation testimony may conjure up for many visions of criminals embarking upon intimidation sprees to "encourage" recantations, there is no indication that such a fear is rationally based. This scenario is quite unlike the situations in which recantations usually occur-namely, trials involving sex crimes ${ }^{77}$ or those in which a codefendant who was a chief witness for the prosecution recants. ${ }^{78}$

It should be emphasized that the ultimate relief that the convict seeks typically is not immediate release but simply a new trial. ${ }^{79} \mathrm{Be}-$ cause of the need for finality of judgments and the scarcity of judicial resources, the courts are well justified in granting new trial motions cautiously. The courts should not be so penurious, however, in cases in which the potential for injustice is so great. "The specter of judicial overwork often fails to materialize, and even if it does it should not be

74 State v. Casey, 201 N.C. $620,624,161$ S.E. 81,83 (1931).

${ }^{75}$ While conclusive presumptions are permitted in civil cases, presumptions must be rebuttable in criminal cases. See generally J. WALTZ, CRIMINAL EvidENCE 275-81 (2d ed. 1983) (discussing the operation of presumptions in criminal cases).

${ }^{76}$ Starr, supra note 1 , at 73.

77 See, e.g., cases collected in Annotation, supra note 6, at 970; see also N.Y. Times, May 9, 1985, at A25, col. 1 (briefly discussing recantations in sex crime cases).

${ }^{78}$ See Berman, supra note 16, at 39 ("Frequently, the recanting witness will be a codefendant, who for reasons of his own, decides to change his story.").

${ }^{79}$ See id. at 46-48 (explaining that "a new trial is the customary order"). 
determinative of an innocent man's freedom."80 If a convicted person is innocent, a new trial will enable the court to correct a heinous error. "Truth will ultimately prevail, and any individual guilty of a crime will finally answer for the same."

Finally, judges considering motions for new trials should be hesitant to apply such a high credibility standard because credibility, as a finding of fact, is only reviewable on appeal if wholly unsupported by the evidence. ${ }^{82}$ Great weight is given to the conclusions of the judge hearing the recantation evidence. ${ }^{83}$ Indeed, judicial discretion in evaluating credibility is currently so great that even when a recanting witness is later tried and adjudged guilty of perjury for original trial testimony, the courts in most jurisdictions are, still not required to grant a new trial. ${ }^{84}$ Lack of meaningful judicial review is especially significant in the recantation area because typically the judge who considers the new trial motion is the same judge who presided at the original trial. Having sentenced and perhaps convicted the defendant, the trial judge may well experience a "natural resistance to reversing"8s and behave defensively with respect to her own and the original jury's credibility perceptions. $^{88}$

Finally, reversal of denials of motions for new trials is difficult because trial judges rarely state the factual bases for their determinations on such motions. ${ }^{87}$ Despite the overwhelming importance of making accurate findings, the factual analyses of recantations by judges considering motions for new trials have been criticized as "usually mere

so Donnelly, supra note 24 , at 38 .

81 People v. Shilitano, 218 N.Y. 161, 195, 112 N.E. 733, 744 (1916) (Hogan, J. and Hiscock, $J$., dissenting).

82 See 3 C. WRIGHT, supra note $14, \S 557.1$, at 344 ; see also DiCarlo v. United States, 6 F.2d 364, 369 (2d Cir. 1925) (holding that denial of a motion for a new trial was not reviewable at all and that an appeal for clemency was the only recourse).

${ }^{83}$ See Shockley, A Chance for A Second Chance: New Evidence and New Trials, 19 TEnN. B.J. 23, 25 (1983).

${ }_{84}$ See Berman, supra note 16, at 39. But see Commonwealth v. McCloskey, 270 Pa. Super. 584, 591-92, 411 A.2d 1239, 1243 (1979) (Cercone, P.J., concurring) (where the very judge who had presided at the recanting witness's perjury trial found an adequate basis for the witness's plea of guilty and later denied the applicant's postverdict motion based upon the same recantation, even the strictest jurisdictions would find an abuse of discretion in denying a motion for a new trial).

85 8A R. CIPES, supra note 7, II 33.03[1], at 33-20 nn. 10-11; see also Donnelly, supra note 24 , at 37 ("Understandably there is a strong reluctance to admit that the state, which maintains right and justice, can commit mistakes . . . .").

${ }_{86}$ See N.Y. Times, Apr. 16, 1985, at A26, col. 1; see also N.Y. Times, Apr. 13, 1985, at A1, col. 1, A6, col. 5 (Sam Adams, a prominent Chicago criminal defense attorney, explains that the Illinois criminal code was changed in 1983 to allow such cases to be brought before different judges because for years attorneys had "complained that it was futile to ask the trial judge to overturn the conviction because of error.").

${ }^{37}$ See Note, supra note 15 , at 181. 
conclusionary statements."

\section{B. Due Process Concerns}

Current treatment of recantations raises serious due process concerns. $^{89}$ In Mooney $v$. Holohan, ${ }^{80}$ the Supreme Court said that a conviction based solely on perjured testimony knowingly used by prosecuting authorities violates a defendant's due process rights to a fair trial. ${ }^{91}$ The same is true when the government knowingly allows unsolicited false evidence to go uncorrected. ${ }^{92}$ Some commentators further believe that it is fundamentally unfair under any circumstances to let stand a conviction based solely on perjured testimony: ${ }^{83}$

The fact that the perjured testimony was unwittingly used by the prosecution does not change the fact that there was state action in indicting, trying and convicting the accused. Nor should the fact that the imprisoned person is serving a sentence for a crime which he may not have committed be ignored. A court appears to do violence to the notion that due process is based upon a concept of fairness when it admits that a miscarriage of justice may have resulted but then says that due process has not been violated. ${ }^{94}$

While many courts have stubbornly clung to an unjustifiably strict and technical concept of "state action," a necessary element in any due process claim, the better reasoned opinions have taken the view that a conviction based upon perjured testimony, even if unknowingly used, results in a constitutional error. ${ }^{98}$ If fundamental concepts of justice

88 Id. at 182.

89 See generally Murray, supra note 25, at 102-07 (discussing the due process questions raised by use of perjured testimony under United States law and the laws of various other countries).

${ }^{80} 294$ U.S. 103 (1935).

91 Id. at 112-13; see also Williams v. United States, 500 F.2d 105, 107-08 (9th Cir. 1974) (ruling that the perjury of a government agent warranted a new trial).

82 See Alcorta v. Texas, 355 U.S. 28, 30-32 (1957); 3 C. WRIGHT, supra note 14, $\S 557.1$, at 341 .

${ }^{83}$ See Murray, supra note 25, at 107, 115-16.

Id. at 106.

9s See Jones v. Kentucky; 97 F.2d 335, 338 (6th Cir. 1938); People v. Cihlar, 125 Ill. App. 3d 204, 211-12, 465 N.E.2d 625, 630 (1984); People v. Shannon, 28 Ill. App. 3d 873, 877, 329 N.E.2d 399, 404 (1975); Riley v. State, 93 Nev. 461, 462, 567 P.2d 475, 476 (1977); People v. Yamin, 45 Misc. 2d 407, 416-17, 257 N.Y.S.2d 11, 22-23 (Sup. Ct. 1965); see also Note, supra note 15, at 182 (effect on accused is the same regardless of the government's knowledge). But see Burke v. Egeler, 512 F.2d 221, 227 29 (6th Cir. 1975) (questioning the validity of a broad reading of Jones, but expressly declining to overrule it). 
condemn convictions obtained through perjured testimony knowingly used, they must "with equal abhorrence condemn as a travesty a conviction [based] upon [even unknowingly used] perjured testimony . . . ."98 It follows that if one cannot effectively challenge a conviction based upon perjured testimony, due process is similarly offended. Specifically, making the new trial standard virtually impossible to satisfy would seem to be as fundamentally unfair as allowing innocent persons to remain incarcerated as a result of knowingly perjured testimony. If it is patently unjust to refuse a new trial when conviction rests solely on testimony known to be perjured, denying the defendant an effective chance to prove perjury is also patently unjust. ${ }^{97}$ Thus, even if "mere recantation" is not in itself a ground for invoking the due process clause against a conviction, ${ }^{98}$ the absence of a realistically attainable remedy for those convicted through perjured testimony is a violation of due process. ${ }^{99}$

Due to the unreasonably high credibility standard courts use, there are few cases in which recantations were credited and new trials were granted. ${ }^{100}$ The current standard is so rigorous that recantation testimony "basically falls on deaf ears."101 This scarcity of successful new trial motions based on recantation testimony suggests that the current standard does not permit a realistically attainable remedy and hence may violate due process. At the very least, a conviction based upon perjured testimony is inherently unfair and compromises judicial integrity. ${ }^{102}$

As the Supreme Court has indicated, where the jury's verdict is tainted by perjured testimony, the courts should be less hesitant to grant a new trial and more eager "to see that the waters of justice are not polluted .... The government of a strong and free nation does

Jones, 97 F.2d at 338.

97 See State v. Mooney, 670 S.W.2d 510, 515 (Mo. Ct. App. 1984). 25 n. 27.

98 See Hysler v. Florida, 315 U.S. 411, 413 (1942); Donnelly, supra note 24, at

99 See Jones v. Kentucky, 97 F.2d 335, 338 (6th Cir. 1938) (requiring states to afford a corrective judicial process to remedy conviction based on perjured testimony).

100 See sources cited supra note 15.

101 TIME, Apr. 22, 1985, at 24, 24 (quoting Thomas Royce, a prominent Chicago criminal defense attorney). See generally 3 C. WRIGHT, supra note $14, \S 557.1$, at 341-52 (stringent judicial standards warranted because motives for recantation are bribery and coercion, not remorse); Note, supra note 15, at 181-82 (new trials are seldom granted regardless of the standard used).

102 See Note, supra note 42, at 1325 ("IA]llowing a conviction to stand in spite of recognized perjury compromises the integrity of the criminal justice system."); see also 8A R. Cipes, supra note 7, I 33.05, at 33 (suggesting that the troubling question is whether a conviction based upon testimony of an admitted perjurer should ever stand); Relief, supra note 24, at 326 ("S]uch convictions undermine the system of criminal justice."). 
not need convictions based upon such testimony. It cannot afford to abide with them."103 Having lost the presumption of innocence at a trial at which perjury may have precluded a finding of reasonable doubt, the defendant may find the burden of proving the trial testimony false so difficult as to be effectively insuperable. ${ }^{104}$ Such a result is patently unfair and raises serious due process concerns.

\section{G. The Executive Clemency Power}

It has been said that "to pardon a man for being innocent is an irony."105 Nevertheless, many persons have voiced the view that the executive clemency power should be used in recantation cases in which the court's credibility standard precludes a fair result. ${ }^{106}$ Whether the American people should ever be satisfied with principles of law that tend to allow incarceration of innocent persons is itself questionable as a general matter. ${ }^{107}$ More specifically, sporadic use of the executive clemency power is not an adequate mechanism for dealing with the problems caused by trial judges who refuse to believe recantations be-

${ }^{103}$ Mesarosh v. United States, 352 U.S. 1, 14 (1956).

106 See N.Y. Times, Apr. 13, 1985, at A1, col. 1, A6, col. 3 (comments by Professor Ronald Allen of the Northwestern University School of Law) (overturning a conviction on the basis of recanted testimony is "very difficult, verging on the impossible."); supra text at notes 76-77; cf. Commonwealth v. McCloskey, 270 Pa. Super. 584, 59192, 411 A.2d 1239, 1241 (1979) (judge had refused to credit recantation for new trial purposes even though he had presided over the recanting witness's perjury trial and had found a factual basis for and accepted a plea of guilty to a charge of perjury).

10 Weihofen, The Effect of A Pardon, 88 U. PA. L. Rev. 177, 192 (1939).

${ }^{108}$ See N.Y. Times, May 14, 1985, at A26, col. 1 (editorial praising clemency as the ultimate solution to recantation problems); Why it's Tough to Take It Back, TiME, Apr. 29, 1985, at 75, 75 (describing clemency as a safety valve).

107 Of course it is quite proper to use the clemency power to correct certain difficult cases, since the law generally cannot be fashioned so as to cover every conceivable situation. See S. Stafford, Glemency: Legal Authority, Procedure and STRUCTURE xvi (1977). But a continuing need for the pardoning power usually "reflects the need for alterations in the system preceeding it." Id. at xvi (citing NATIONAL Advisory Commission on Griminal Justice Standards and Goals, CorrecTIONS 591 (1973) (standard 16.16)).

It is interesting to note that the criminal justice system typically employs rules that provide for the release of individuals who may well be guilty, so as to ensure the protection of the innocent-the exclusionary rule, for example. In the recantation area, however, the emphasis seems to shift to ensuring that the guilty remain incarcerated, even if it means that innocent persons might share their cells. This shift may be due to a belief that unjust convictions are uncommon. See Note, Eligibility for Certificate of Innocence under Federal Erroneous Convictions Act, 15 U. CHI. L. REv. 773, 775 (1948) ("The widespread indifference to the plight of the victim of an unjust conviction in this country is probably attributable to the notion that occurrences of this kind are too rare to justify public concern."). But since disclosure of errors leading to unjust convictions often depends on the "fortuity of press notoriety," Donnelly, supra note 24, at $22 \mathrm{n.7}$, it must be assumed that many such errors go undetected. 
cause of an unrealistically high credibility standard.

The authority to grant pardons originated in the earliest civilizations. ${ }^{108}$ It has been criticized frequently through the centuries. ${ }^{100}$ In medieval England, for example, critics claimed that pardons were more often granted for unrelated motives, such as for military necessity, than for correcting judicial errors. ${ }^{110}$ Use of the clemency power was further criticized for substituting administrative discretion for judicial decision and for making judgments uncertain rather than predictable. ${ }^{111}$ In modern times, the clemency power includes authority to grant a pardon or reprieve, commute a sentence, or remiss a fine or forfeiture. ${ }^{112}$ It is justified as a means of modifying the results of inflexible rules of law that may persist from a time laws were seen as static and inelastic and thus not subject to social reform. ${ }^{113}$

Although the executive clemency power certainly plays an important role in our system of justice, use of the executive power as a panacea for injustices caused by applying static rules regarding recantations to motions for new trials undermines confidence in our judicial system. There is an understandable tension among the branches of government regarding the proper use of the clemency power. ${ }^{114}$ How the public views this tension is perhaps even more important than such tension itself. When a seemingly plausible recantation is rejected by a court, the public may believe that the trial judge is keeping an innocent person incarcerated only because the judge is reluctant to admit responsibility for convicting that person. ${ }^{115}$

Although the executive can competently entertain petitions for clemency, the "executive's justice" may be meted out in varying degrees, depending upon the political climate of the times ${ }^{116}$ or the per-

108 See National, Council on Grime and Delinguency, The Historical Background of Clemency, in Clemency IN Pennsyluania § I.01-.05 (1973).

${ }_{109}$ See id. \& I.10-.12.

110 See N. Hurnard, The King's Pardon for Homicidf: Before A.D. 1307, at vii (1969).

111 See id. at vii-xiv.

112 See S. STAFFORD, supra note 107, at xiii (1977).

113 See id. at xiv-xv.

114 See id. at 1.

116 See N.Y. Times, Apr. 16, 1985, at A26, col. 1 (stating that courts have generally resisted pleas to overturn a conviction due to recantation and recommending that the governor of the state intervene to commute a sentence where the state courts refuse to overturn a conviction based on perjured testimony).

${ }^{176}$ See S. STAFFord, supra note 107, at xv; N.Y. Times, May 20, 1985, at A12, col. 2 (alleging that governor held clemency hearings and commuted sentence as a means of diverting public attention from other issues); see also Donnelly, supra note 24 , at $25 \mathrm{n} .27$, in which it is noted that clemency was not granted in a particular recantation case because the governor involved had made a campaign promise not to use the pardon power if he were elected. 
sonal beliefs of the executive with the power to grant clemency. The crucial nature of the personal beliefs of the empowered individual is dramatically demonstrated by a case in which an innocent man was convicted of murdering a man who was actually murdered by the decedent's wife. ${ }^{117}$ The wife, then pregnant, had orchestrated the innocent man's conviction through her daughter's perjured testimony because she did not wish her unborn child to begin life in prison. After giving birth, she vindicated the man and pleaded guilty to the crimes of murder and perjury. The judge, exercising his statutory discretion, suspended her sentence. The innocent man's fate was left to the governor, who decreed: "Somebody ought to be in the penitentiary all the time for the murder of a sleeping man. If Judge Pegram does not bclieve Mrs. Drew is guilty enough to serve her term, then the man convicted of the murder will have to serve his term."118

The executive clemency power, even when fully exercised, does not always provide an adequate remedy to persons who are wrongly convicted. Even after a full pardon, the wrongful conviction can be used to discredit the innocent person as a witness, disqualify her as a judge, or form the basis for a refusal of application for naturalization or for a license to engage in a business or a profession. ${ }^{119}$ Further, a pardon may be subject to any condition that the executive chooses to impose. ${ }^{120}$ Clearly, innocent persons would prefer vindication through a new trial to a grant of clemency by the executive. ${ }^{121}$

Particularly in the recantation context, a grant of clemency by the executive may put the judiciary in the uncomfortable position of considering a new trial motion with the realization that the defendant cannot be reimprisoned for the same crime. ${ }^{122} \mathrm{~A}$ judicial determination of innocence, however, would return certain privileges to the defendant and vindicate her name more thoroughly than a grant of clemency. Moreover, since the grant of clemency precludes further punishment but not retrial, the defendant has nothing to lose by seeking another trial. Finally, the possibility that duress has been used to obtain the recantation is not lessened when executive clemency or pardon is granted instead of a new trial. There is no logical reason for those who would coerce a recantation in order to get a new trial to act any differently to secure a

117 See E. BorChaRD, supra note 18 , at 342-44.

118 Id. at 344.

11. See Donnelly, supra note 24, at 31-32; see generally Weihofen, supra note 105, at 179-91 (discussing conflicting views on the effects of a pardon).

120 See J. Cook, Constitutional Rights of the Accused: Post-Trial

Rights, The Pardoning Power $\S 41$ (1976).

121 See Weihofen, supra note 105, at 192-93.

122 See N.Y. Times, May 14, 1985, at B9, col 1. 
grant of clemency if they believed such a grant was within their grasp.

\section{The MiNORITy APPROACH}

Perhaps because of the concerns raised by an overly stringent credibility standard, some courts have taken a different approach to the treatment of recantation testimony. The view of these courts is that a distinction should be drawn between typical recantation cases and cases in which the victim or sole prosecuting witness has recanted and the remaining evidence alone is not adequate to uphold the conviction. ${ }^{123}$ Of those states that endorse this view, Washington has taken the boldest action. The Washington courts have squarely held that when a defendant is convicted solely on the testimony of a witness who later recants, it is an abuse of discretion not to grant a new trial and no finding as to the credibility of the recantation is a prerequisite to a new trial. 124

Such a rule also seems to prevail in Pennsylvania, ${ }^{125}$ although there it has met with some criticism for purportedly limiting the traditional treatment of recanting co-conspirators and cofelons. ${ }^{126}$ Other states in which courts have granted new trials where the evidence other than that provided by the recanting witness was insufficient for conviction include Arkansas ${ }^{127}$ and Michigan, ${ }^{128}$ among others. ${ }^{128}$ Pervading

${ }^{223}$ See Bussey v. State, 69 Ark. 545, 546-47, 64 S.W. 268, 269 (1901); People v. Smallwood, 306 Mich. 49, 51-55, 10 N.W.2d 303, 305 (1943); Commonwealth v. Mosteller, $446 \mathrm{~Pa}$. 83, 90, 284 A.2d 786, 789 (1971); State v. York, 41 Wash. App. 538, 543, 704 P.2d 1252, 1255 (1985).

${ }^{124}$ See State v. Rolax, 84 Wash. 2d 836, 838, 529 P.2d 1078, 1079 (1974); State v. Powell, 51 Wash. 372, 374, 98 P. 741, 742 (1909); York, 41 Wash. App. at 543, 704 P.2d at 1255. An approach demanding an automatic grant of a new trial under such circumstances was similarly adopted in Florida but has since been abandoned. See Borgess v. State, 455 So. $2 d$ 488, 491 (Fla. Dist. Ct. App. 1984) (Ervin, C.J., concurring).

125 The Pennsylvania Supreme Court stated in Commonwealth v. Mosteller:

[W] here as here the defendant's conviction is based completely on the testimony of the child prosecutrix and the truth of that testimony is open to serious question because of the testimony of a disinterested medical witness, a subsequent recantation of testimony as supported by this record necessitates a new trial.

Mosteller, $446 \mathrm{~Pa}$. at $90,284 \mathrm{~A} .2 \mathrm{~d}$ at 789 .

${ }_{128}$ See id. at 95, 284 A.2d at 791 (Pomeroy, J., dissenting) (accusing majority of paying only lip service to its prior review standard while actually severely limiting discretion of lower courts to decide whether to grant new trials based on recantations of victims of sex crimes).

127 See Bussey v. State, 69 Ark. 545, 546-47, 64 S.W. 268, 269 (1901) (holding that it was an error to refuse to grant a new trial where a rape conviction was based almost exclusively on a recanting witness's testimony); see also Roath v. State, 185 Ark. $1039,1050-51,50$ S.W.2d 985, 989 (1932) (stating that a new trial should be granted where witness repudiates material evidence essential to the verdict); Myers v. State, 111 Ark. 399, 415, 163 S.W. 1177, 1182-83 (1914) (holding that it was reversible error to 
the opinions of the courts of these states is what seems to be an underlying belief that in such cases the credibility decision should be left to the jury. ${ }^{130}$ Some cases appear to argue that the credibility decision should be left to the jury in all recantation cases. In Hines $v$. Commonwealth, ${ }^{131}$ for example, the court stated:

The jury found upon the original evidence that the defendant was guilty beyond a reasonable doubt .... But the vital facts upon which that verdict was based were disputed, and this new evidence, if they had heard and believed it, would necessarily have produced a different result. We do not undertake to say what weight a jury would give to the new evidence; but it certainly ought to change the result if it is worthy of belief, and whether it is worthy of belief is a question which ought to be settled, not by the court, but by a jury. ${ }^{132}$

The strongest cries for leaving the credibility determination to the jury have come from dissenting opinions. ${ }^{133}$ One noted a "reluctance to entrust plenary powers over the life and liberty of the citizen to one judge or to a group of judges."134

Referring the credibility inquiry to a new jury in cases in which the victim or sole prosecuting witness has recanted and the remaining evidence alone cannot be considered adequate to uphold the conviction eases at least two concerns raised by traditional treatment of recantations. It eases due process concerns because it ensures that in such cases one can effectively challenge a conviction based upon perjury, ${ }^{136}$ and it ensures adequate review on appeal. ${ }^{136}$ The latter is especially true be-

refuse to grant a new trial where, apart from the recanted testimony, the remaining evidence would have been insufficient to convict).

${ }_{128}$ See People v. Smallwood, 306 Mich. 49, 54-55, 10 N.W.2d. 303, 305 (1943) (holding that it was an error not to grant a new trial where there was a showing of hostile motive on the part of a recanting witness).

128 See cases collected in Annotation, supra note 6, at 907, 918-23.

130 See, e.g., Bussey, 69 Ark. at 547, 64 S.W. at 269 (stating that "whatever the truth may be, whether the defendant be guilty or innocent, it can be established by another trial"); State v. York, 41 Wash. App. 538, 544-45, 704 P.2d 1252, 1255-56 (1985) (arguing that credibility determination should be made by jury),

131136 Va. 728,117 S.E. 843 (1923).

132 Id. at $750-51,117$ S.E. at $849-50$.

1ss See, e.g., Smith v. State, 141 Conn. 202, 215, 104 A.2d 761, 766 (1954)

(O'Sullivan, J., dissenting); People v. Shilitano, 218 N.Y. 161, 195, 112 N.E. 733, 744 (1916) (Hogan, J., dissenting).

134 Commonwealth v. Coleman, $438 \mathrm{~Pa}$. 373, 379-80, 264 A.2d 649, 652 (1970)

(Roberts, J., dissenting) (citing Duncan v. Louisiana, 391 U.S. 145, 156 (1968)).

13s See supra notes 89-104 and accompanying text.

130 See supra notes 82-88 and accompanying text. 
cause referring the credibility inquiry to a new jury alleviates the concern that the trial judge considering the recantation motion will be hesitant to reverse the factual findings on which she had passed judgment. Referring the credibility inquiry to the jury only in cases devoid of supporting evidence would do little, however, to abate the aforementioned concerns in cases where there is other circumstantial evidence present, whether by sheer happenstance ${ }^{137}$ or through human manufacture. ${ }^{138}$ Thus, the development of a standard that could take into account all recantation cases is more desirable than the minority approach.

\section{Proposal for an Alternative Analysis}

\section{A. The Reasonable Possibility Approach}

The credibility standard used to judge a recantation asserted as a ground for a new trial should be relaxed in order to make new trials easier to obtain in cases where suspicion and distrust are less warranted. This relaxation could be achieved through use of the standard proposed below while still ensuring that new trials are not available to manipulative defendants seeking to perpetrate fraud upon the courts. The Reasonable Possibility Approach would provide as follows:

Where the recanting occurred under specific circumstances reasonably free from suspicion of duress or improper motive, and, upon a new trial the original trial testimony reasonably could be found false, a new trial will be granted-provided, however, that the other applicable requirements for a new trial are met. ${ }^{139}$

The remainder of this Comment will discuss this proposed standard. ${ }^{140}$

197 See generally S. Phillips, Famous Cases of Gircumstantial Evidence (1979) (discussing the theory of presumptive proof and providing 32 cases in which circumstantial evidence pointed to the wrong person).

${ }^{138}$ While at first blush evidence created by human contrivance may seem a farfetched notion, it should be noted that even in the recantation case used as the anecdotal introduction for this Comment, the recanting witness claimed to have created the evidence to support her story. See supra note 1.

${ }^{139}$ It is not the purpose of this Comment to propose significant changes in the requirements for a new trial other than the basic credibility inquiry. The proposed standard is intended to enable a court to make a preliminary credibility determination so that it could then apply new trial motion criteria in accordance with Larrison v. United States, 24 F.2d 82 (7th Cir. 1928), and Berry v. State, 10 Ga. 511 (1851). For example, once the two-pronged credibility inquiry proposed above is favorably completed, a court may grant a new trial if: (a) a different result might be reached if the recantation is credited, (b) the evidence has been discovered since the trial, and (c) the evidence could not have been discovered before trial by the exercise of due diligence.

${ }_{140}$ This is an appropriate place to note that this Comment does not seek to ad- 
The elements involved will be explored in more detail and considerations in implementing the standard will be discussed.

\section{The "Reasonably Free from Suspicion of Duress or Improper Motive" Element}

The first element of the proposed standard contains two distinct, though interrelated, requirements. First, the phrase "under specific circumstances" affirmatively requires an analysis of the specific factual situation in each case and expressly rejects any presumption regarding untrustworthiness as a general matter. The entire first requirement is intended to be a replacement for the presumption of untrustworthiness.

Secondly, the phrase "reasonably free" is employed in order to make clear that mere speculation as to duress or improper motive is not sufficient. For example, a judge could not rely solely on there being "something suspicious" about a witness's recanting because such reliance would in effect amount to indulgence in a presumption of untrustworthiness. On the other hand, a judge could find that the recantation of a codefendant who had been subjected to pressure from fellow inmates was not, under those specific circumstances, reasonably free from suspicion of duress or improper motive. ${ }^{141}$ If a judge's finding on the "reasonably free" requirement is adverse to the applicant, the judge would retain discretion to deny the new trial motion. While this aspect of the proposed standard may seem somewhat lacking in precedential support, some courts have employed similarly phrased language in recantation cases. ${ }^{142}$

\section{The "Reasonably Could Be Found False" Element}

The major difference between the proposed standard and current standards is that this element shifts the credibility focus from the judge ruling on the new trial motion to the factfinder at the new trial. Such a focus is not a novel one, as it has been advocated by a number of courts for some time. ${ }^{143}$ In those cases in which the recantation is so incredible

dress the issue of whether the time limit for filing a motion for new trial based upon newly discovered evidence, which is two years in the federal courts, is fair or should be abandoned. See generally 3 C. WRIGHT, supra note 14, § 558, at 361-63 (explaining the time limit and briefly noting the argument against imposing any time limit at all on such motions).

141 See, e.g., State v. Carter, 66 N.C. App. 21, 31-32, 311 S.E.2d 5, 11 (1984).

142 See, e.g., State v. Mooney, 670 S.W.2d 510, 516 (Mo. Ct. App. 1984); State v. Fuentes, 66 N.M. 52, 60-61, 342 P.2d 1080, 1085 (1959).

${ }_{143}$ See e.g., Lombardo v. State, 172 Conn. 385, 393, 374 A.2d 1065, 1069 (1977) (Bogdanski, J., dissenting) (arguing that a new trial motion should not be denied just 
that the original trial testimony could not reasonably be found false, the judge would retain discretion to deny the new trial motion. In those cases, however, in which it appears that in a new trial the original trial testimony reasonably could be found false, it would be error not to grant a new trial.

Thus, the proposed standard falls between two extreme approaches, one advocating that credibility be left entirely to the jury, ${ }^{144}$ and the other, that credibility be left entirely to the judge, ${ }^{145}$ in order to achieve a test that is both workable and equitable. If adopted, the proposed standard would effectively reduce the defendant's burden of proof on the issue of credibility. It would also help to dispel the fear that the judge hearing the recantation evidence, typically the same judge who presided at the trial, may be overly reluctant to reverse. ${ }^{146}$ Finally, the proposed standard would provide for greater reviewability on appeal because it would require that specific factual findings be made. ${ }^{147}$

\section{B. Considerations in Implementing the New Standard}

While it is impossible to enumerate all the considerations involved in making a decision on a motion for a new trial based upon recantation evidence, some are particularly worth noting. First, in determining whether the recantation occurred under specific circumstances reasonably free from suspicion of duress or improper motive, the personal relationship between the recanting witness and the defendant might be considered because of its strong probative value on the issue of motivation. ${ }^{148}$ A judge might thus justifiably consider the credibility standard to be met by the defendant to be somewhat higher in cases of incest $^{\mathbf{1 4 9}}$ or in codefendant cases where the recantor and petitioner are

because the trial judge refuses to believe the evidence and that the test should be whether the jury could reasonably extend credibility to it); Smith v. State, 141 Conn. 202, 214-18, 104 A.2d 761, 766-68 (1954) (O'Sullivan, J., dissenting) (advocating the granting of a new trial motion if there is a "reasonable probability" that jury will believe the new evidence); see also supra note 131.

144 See People v. Shilitano, 218 N.Y. 161, 195-99, 112 N.E. 733, 744-46 (1.916) (Hogan, J., dissenting).

${ }_{145}$ See id. at 180, 112 N.E. at 739 (Cardozo, J., concurring); 3 C. WRIGHT, supra note $14, \& 557$, at 336-37.

${ }_{146}$ See supra notes 85-86 and accompanying text.

117 See generally supra notes 87-88 (explaining that under present law judges rarely state the factual basis for their determinations).

148 See, e.g., State v. Salinas, 129 Ariz. 364, 631 P.2d 519 (1981) (noting that because the recanting witnesses were a friend and a relative of the defendant's, their credibility was affected).

${ }_{140}$ False recantations by sexually abused children are not uncommon. The improper motives that induce such recantations include guilt and pressure from family members. See N.Y. Times, May 9, 1985, at A25, col. 1. 
cellmates. ${ }^{150}$ This is not to say that there should be a presumption that the recantation is generally more suspect in such situations, but rather that the lack of an arm's length relationship should be considered in determining whether the recantation is reasonably free from suspicion of duress or improper motive. When inquiring into motivation, a court may properly limit its consideration to whether there is any evidence of a stronger motivation to make a false recantation than to give false trial testimony.

Second, in determining whether in a new trial the original trial testimony reasonably could be found false, an important consideration is whether the recanting witness's testimony places the occurrence of the crime itself in dispute ${ }^{151}$ or leaves the verdict stripped of evidence sufficient to sustain it. ${ }^{152}$ Numerous other factors may need to be considered, depending on the facts of each case. Those factors normally considered by judges in evaluating credibility, such as the witness's demeanor, would also remain relevant. ${ }^{163}$

How these considerations could be employed in implementing the proposed standard can best be illustrated through the use of two hypotheticals. Suppose that D1 has been tried and convicted of sexually molesting V1, his minor daughter. At the trial, the medical evidence was consistent with a finding of a continuing incestuous relationship and the girl's elementary school teacher testified that V1 gave detailed accounts of the assaults. Since the conviction, the girl has been living with an elderly aunt. After returning from a visit to see her father at prison, the girl becomes despondent. She asks when her father can come home and is told it will be ten years. V1 then recants. Under the proposed standard the burden of proving the veracity of the recantation rests with $\mathrm{D} 1$, but he will not be burdened by a presumption of untrustworthiness. Due to the lack of an arm's length relationship, however, and because the recantation came shortly after the girl became distraught over her father's imprisonment, a judge might well conclude

150 See State v. Sims, 99 Ariz. 302, 310, 409 P.2d 17, 22 (1965) (noting that a prisoner serving a life sentence has little to lose by assisting another defendant to avoid punishment).

151 See generally N.Y. Times, May 9, 1985, at A25, col. 1 (Norval Morris, a professor of law and criminology at the University of Chicago, expresses the view that the usual restrictive rules on recantations should not apply when the "victim" later claims the crime never occurred.).

102 See 3 C. WRIGHT, supra note 14, $\S 557$, at 323-24 n.21; supra notes 123-38 and accompanying text.

${ }_{183}$ See, e.g., State v. Carter, 69 N.J. 420, 427-28, 354 A.2d 627, 631-32 (1976) ("Manner of expression, sincerity, candor and straightforwardness are just some of the intangibles available to the trial judge in evaluating the credibility of recantation testimony."). 
that the recantation had not occurred under specific circumstances reasonably free from suspicion of duress or improper motive.

Now suppose that D2 has been tried and convicted of car theft. At trial, the evidence showed that D2 was in possession of V2's car and V2 testified to seeing D2 remove it from V2's driveway. V2 was in the habit of leaving the keys in the glove compartment. D2 claimed to have met V2 a few days earlier at a party where V2 had given D2 permission to use the car. One year after D2's conviction, V2 recants, admitting to perjury and that D2 had permission to borrow the car.

In this case, there are no specific circumstances indicating duress or improper motive. The parties have an arm's length relationship and there is no evidence of a stronger motivation to give a false recantation than to give false trial testimony. Therefore, this recantation would likely satisfy the "reasonably free from duress" test. The recantation would next be analyzed under the "reasonably could be found false" test. In this second hypothetical, the recantation leaves the verdict stripped of evidence sufficient to sustain it and even places the occurrence of the crime in dispute. Taking into account the witness's demeanor and other factors, the factfinder at a new trial could reasonably find that the trial testimony had been false and that the recantation is true. Thus, a new trial would be granted.

These examples indicate that the proposed standard would continue to limit the granting of new trials. The proposed standard may seem somewhat lax if literally applied and may even cause some to express anew old fears concerning the indiscriminate granting of new trial motions. ${ }^{154}$ But it should not be forgotten that such criticism proved empty when aimed at the Larrison standard. ${ }^{155}$

The proposed standard seeks to reject the unjustifiably strict and static recantation rules that currently blanket the country. Regardless of what else might be said regarding the treatment of recantations, one thing cannot be denied: "The worst consequence of granting the [new trial] motion is that the state will have the expense of another trial. . . . [T] ]he worst consequence of denying the motion is that the defendants remain convicted of a crime which they might not have committed." Ass one judge concluded, "But $I$ think justice is more im-

1st But see People v. Shilitano, 218 N.Y. 161, 195, 112 N.E. 733, 744-46 (1916) (Hogan, $J$., dissenting) (stating that the risk of convicting an innocent person is a greater evil than the danger of establishing a precedent that would enable former witnesses to trifle with the administration of justice by permitting them to confess to perjury and enable one convicted of a crime to secure a new trial). $180-81$.

185 See 3 C. WRIGHT, supra note $14, \S 557.1$, at 346-47; Note, supra note 15 , at

${ }^{158}$ State v. Keely, 101 Idaho 711,712 n.4, 620 P.2d 284, 285 n.4 (1980). 
portant than expense." "157

\section{ConCLUSION}

Our courts need to rethink carefully the current treatment of recantations, especially in those cases in which a victim or sole prosecuting witness recants apparently without threat, bribe, or other improper influence. The courts must structure the credibility inquiry in recantation cases to provide a realistic judicial solution for instances in which an arguably innocent person has been incarcerated for a crime which may not have even occurred. ${ }^{168}$ Until judicial provision is made for such instances, denials of motions for new trials in these "unusual" cases will continue to arouse public outcry and erode confidence in our judicial system. ${ }^{\mathbf{1 6 9}}$

${ }^{157}$ Id. at 712,620 P.2d at 285 (citing the unpublished opinion of the trial judge).

${ }_{188}$ While the judiciary is the most likely organ to reform the treatment of recantations, state legislatures could also accomplish reforms.

${ }_{180}$ It should be noted, however, that the public outcry over the Webb-Dotson controversy, see supra notes 1-6 and accompanying text, might well have resulted even under the standard proposed herein, because that outcry erupted following denial, not of a new trial motion but apparently of a motion to vacate. See Black, Why Judge Samuels Sent Gary Dotson Back to Prison, 71 A.B.A. J. 45, 45 (1985). Under the analysis suggested in the proposed standard, it seems clear that Dotson should have been entitled to a new trial. Judge Samuels, however, should not be criticized for his decision: "[T]he learned and upright judge who tried this case followed the almost unbroken current of authority." Hines v. Commonwealth, 136 Va. 728, 750, 116 S.E. 843, 849 (1923). 
